
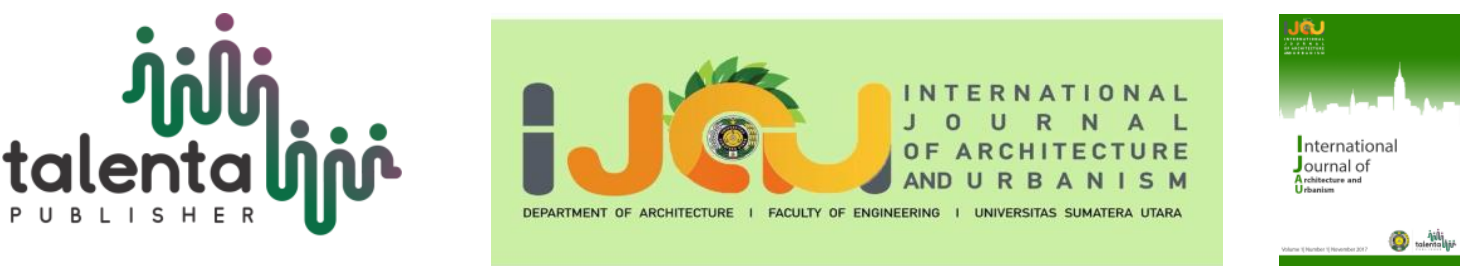

\title{
Creativity Center for Child-Friendly Settlements in Kampung Hamdan-Sukaraja With Behavioral Architecture Approach
}

\author{
Rudolf Sitorus $^{1}$, Sania Ariany Siregar ${ }^{*}$ \\ ${ }^{I}$ Departement of Architecture, Faculty of Engineering, Universitas Sumatera Utara, Medan, Indonesia
}

\begin{abstract}
Childhood is a phase of human growth that is very important in the growth of one's soul. One of the factors for a person's character building is creativity that can be formed early on. Children's creativity can be provided by informal education for children through their families and environment. Meanwhile, children in this age of technological development are often given gadgets by their parents, so that children today prefer digital games, which can trigger apathy towards others and reduced creativity space for children. Therefore, the aim is to design a Creativity Center for Child-Friendly Settlements in KampungHamdan-Sukaraja to provides a platform for the development of children's creativity and interest through play and learning activities by presenting social values and local cultural values. This Creativity Center uses the problem-solving methodology approach to solve existing problems, starting from the formulation stage, location surveys, data collection, literature studies, and comparative studies. The Children's Creativity Center is designed simply in terms of material use and affordable handling costs for the community of Kampung Hamdan-Sukaraja. The Creativity Center uses a Behavioral Architecture concept that makes each space designed to be comfortable and safe according to children's needs and this expected to benefit for providing child-friendly spaces in Kampung Hamdan-Sukaraja as a child-friendly settlement in Medan City for increasing children's creativity.
\end{abstract}

Keyword:child-friendly, children, creativity, education

Received 20-11-2020 |Revised 4-1-2021 | Accepted 8-1-2021

\section{Introduction}

Creativity is one of the assets in human development. An ability to make new combinations, based on data, information, or elements known previously in the form of experience, a knowledge that has been obtained by someone [1]. As one of the determinants of the quality of human resources, the creativity of every individual should be developed since childhood to increase his potential.

\footnotetext{
*Corresponding author at:Department of Architecture, Faculty of Engineering, Universitas Sumatera Utara, Perpustakaan st. Building J07, Medan, 20155, Indonesia 
Children are the initial figures of an individual to carry out a process of rapid development for themselves. Childhood isavital phase of growth because of intellectual development and creativity as well as the formation of character that will determine their soul later in adulthood [2]. Children's creativity can emerge through various efforts, one of which is informal education.Informal education is necessary to maintain a balance between learning and play through learning by doing methods [3]. Playing activities is necessary for children tostimulate creativity and the power of thinking optimallywithout feeling forced to do so [4]. Informal education has given to every child from birth and throughout his life which is the basis for the formation of habits, character, and behaviour of a person in the future. The family and the surrounding environment play asignificant role in providing informal education[5]. The role of the family is to provide care and socialization for children. With socialization, children get good values and behaviour from family members, especially parents [6].

However, in reality, at this time the development of technology has affected the daily life of children, including children in Medan City. The habits of today's parents who cannot separate from gadgets make them introduce these gadgets and digital games to their children to help the process of developing creativity simpler and more efficient in terms of time and place. As a result, children become less socially interacting with their environment, the formation of their character is more self-centred, and they also become unfamiliar with local cultural values [7]. The participation of children as the successor to the nation has asignificant meaning in maintaining local culture and advancing the Indonesian nation[8].

Kampung Hamdan-Sukaraja is two dense residential in Medan City. These two villages are located alongside and bounded by the Deli River in the middle. The level of social interaction and children's interest in playing with their peers is still relatively high in the Hamdan and Sukarajaneighbourhoods. They like to play on the field in the middle of the settlement and also on the riverbank. However, the influence of gadgets and the environment still exists, so that makes them unfamiliar with local cultural values. In fact, by playing traditional games, children can preserve Indonesian culture so that it does not become extinct amid the times while at the same time hone their thinking and creativity.Because traditional games involve all aspects of development, such as motoric, cognitive, language, and socio-emotional children [9].

\section{Literature Review}

\subsection{Creativity Center for Child-Friendly Settlements}

Is a forum that facilitates children's activities to develop creativity, informal education and serve as a means of education, recreation, and introduction of cultural values and local wisdom and as an embodiment of friendly and proper settlements to fulfilthe rights of the child. 
2.2 Behavioural Architecture

Behavioural Architecture is a humane architecture, capable of understanding and accommodating human behaviour from a variety of behaviours, be it the behaviour of the creator, user, observer, as well as the behaviour of the surrounding nature [10].

The choice of the Behavioral Architecture theme for the design of the Center for Children's Creativity was based on the use of facilities aimed at children. In this design, a child's behaviour approach was needed, considering the children's needs in activities must be given special attention so that they get comfort and safety. Each room created will be adjusted to the pattern of behaviour and needs of children in using space so that the child's interest to learn while playing at the Children's Creativity Center will be higher [11].

Reference [12] based on standards by the National Association for the Education of Young Children (NAEYC), the provision of child-friendly play and learning containers that can accommodate the characteristics of children's behaviour is to provide physical activity space, Encourage self-expression, Encourage independence, Appropriate for Children, Atmosphere like Home, Provides Natural, Structured and Flexible Space, Safe, Protected and Healthy, Effective space for parents and teachers.

\section{Methodology}

The stages of the study began with the selection of locations for the "Creativity Center for Child-Friendly Settlements in Kampung Hamdan-Sukaraja" by considering elements or requirements that were by the established design conditions such as; spatial plans, reviewing government regulations for urban structures, and city utilities. After that, it takes thedata collection method, which is classified into two types. Primary data is results of field surveys, interviews, identify problems and potential problems that exist on the site. Meanwhile, secondary data is data from literature books, scientific journals, and comparative studies of similar project. Next, all data are collected in the analysis to solve the design problem. The results of the analysis produce a design concept.

\section{Result and Discussion}

\subsection{Design Location}

The location of this project is in the MedanMaimun District. According to RDTR (Rencana Detail Tata Ruang) and Medan City Zoning Regulations, the arrangement of Medan Maimun as a trade / business activity centre, service activity centre, city and provincial government centre, and economy service centre [13]. The selected location is in the Ir. H Juanda street, in Kampung Hamdan-Sukaraja. Kampung Hamdan - Sukaraja is the name of a settlement with densely populated settlements located right on the banks of the Deli River. This location meets the 
criteriafor site selection and requires appropriate public area for children as a place for them to learn, play and develop their creativity. This location also requires handling related to the slums that occur around the deli river, especially in the centre of Medan City. Based on calculations from satellite maps, the planning location has an area of around $16,000 \mathrm{~m}^{2}$ or 1.6 hectares (Figure 1).

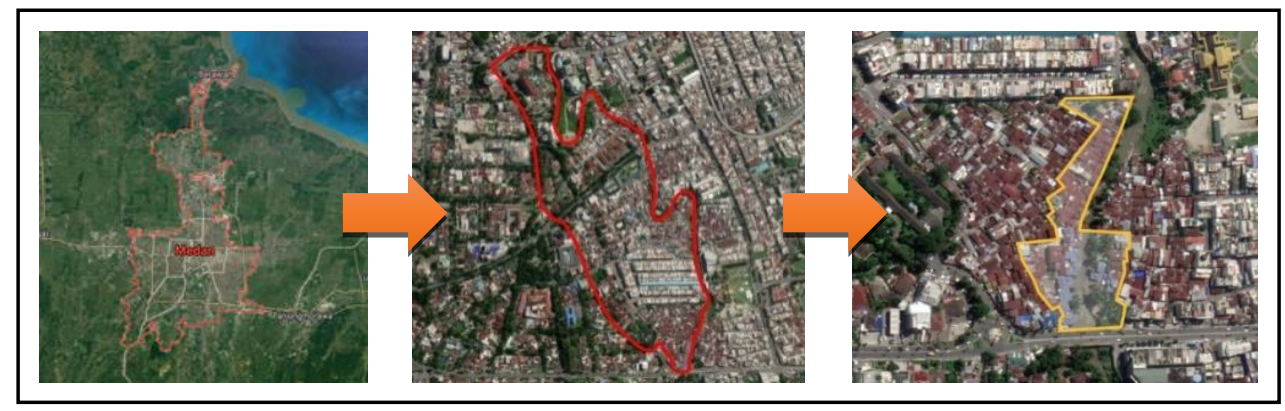

Figure 1 Project Location

Based on the Medan City Spatial Plan Pattern Map, the planning location is in a mediumdensity residential area (R-2) and trade (K-1) (Figure 2).

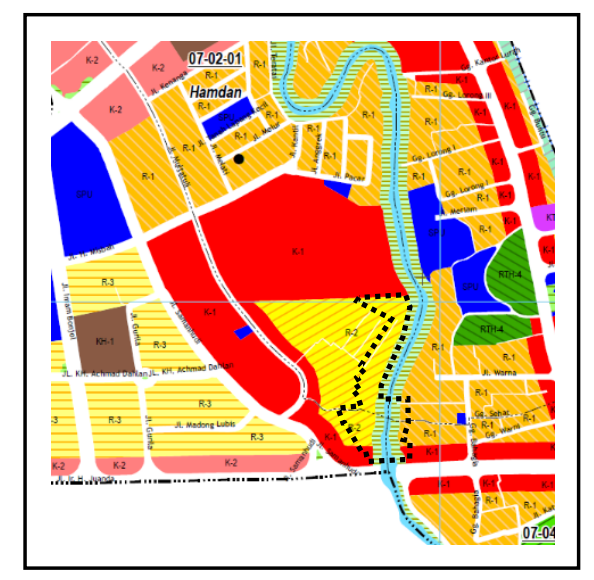

Figure 2 Map of Medan City Spatial Plan Pattern

\subsection{Zoning Concept}

Zoning of the site is divide into four areas: public, semi-public, private, and service. Public area will be used as open spaces and pedestrian paths. The semi-public area is used as an area of children's creativity, and the private area is a vertical residence for Hamdan and Sukaraja residents. Service area as laying utility requirements (Figure 3). 


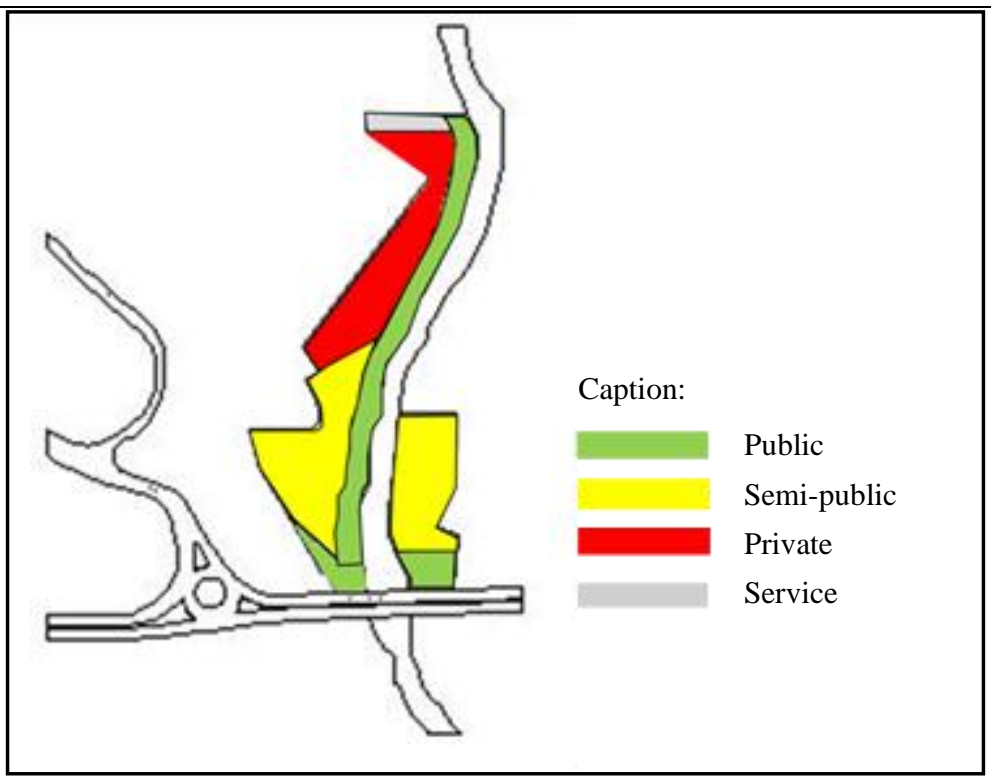

Figure 3 Zoning

This design uses a multi-mass concept which was divided into five types of mass, namely the secretariat building, creative centre building, craft cottage, vertical residence, and public bathroom. Circulation between masses uses a linear model in which each mass is connected by footpaths and also open space (Figure 4).

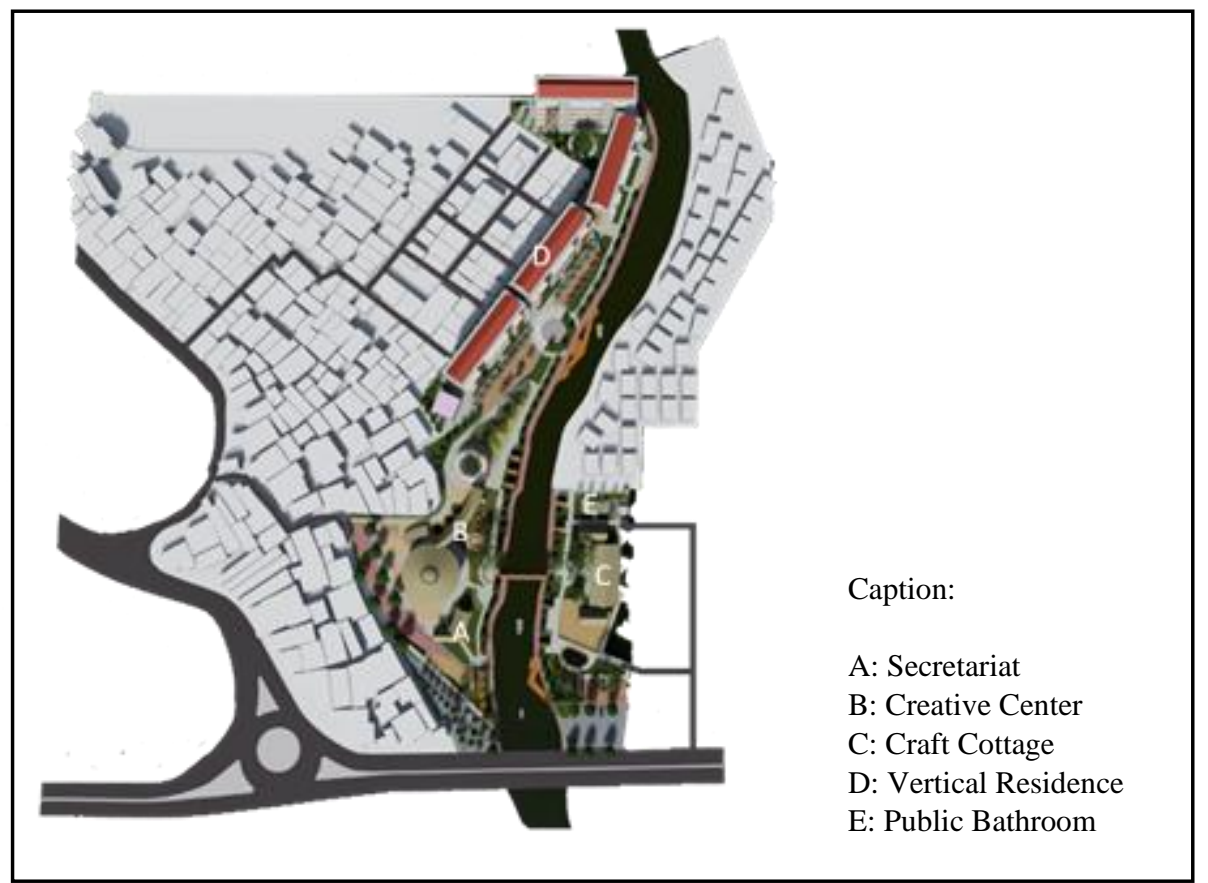

Figure 4 The Concept of Multi-Mass

\subsection{Accessibility Concept}

Access to this site was divided into three types, namely: (1) Ir. H. Juanda street, which is the main entrance that can be accessed by all users and vehicles. (2) Then through the entrance from the Kampung Hamdan - Sukaraja in the form of small alleys which will later serve as a boundary between the centre of creativity and residential residents. Some aisles are also 
designed as "Child-Friendly Path". (3) Furthermore, through the pier as access to enter the river by users who come using the ship (Figure 5).

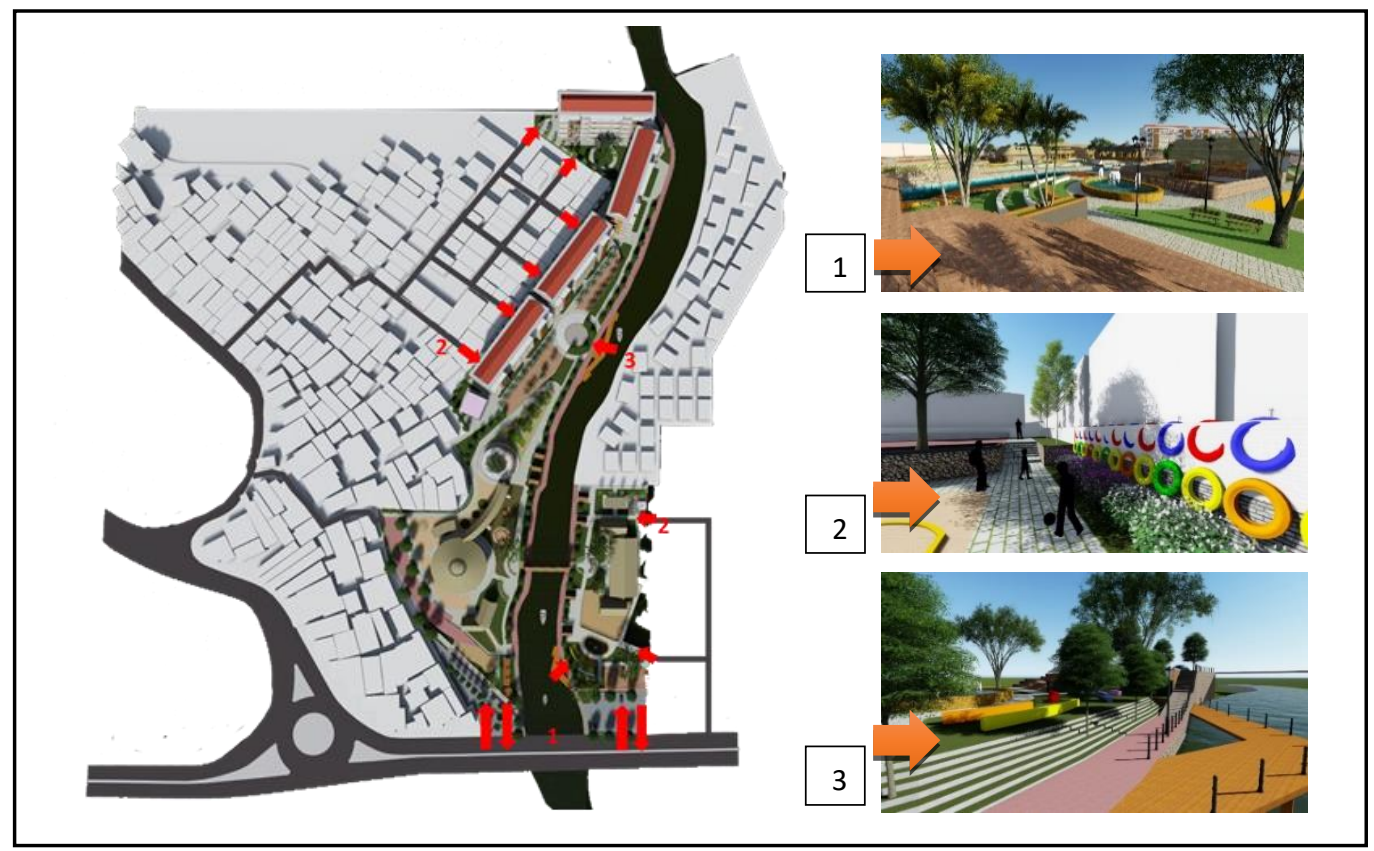

Figure 5 Site Entrance

\subsection{Circulation Concept}

The circulation concept in this site is only accessible to pedestrians. Car and motorcycle can only reach the site limited to a parking area. Between building, masses is also connected by a linear circulation path consisting of: (1) Pathways, being the prime circulation that connects building mass and as a proper pedestrian pathway for supporting public spaces. (2) Promenade of the river becomes a circulation as well as public space to enjoy the space on the riverside. (3) Bridges that cross the river to connect Kampung Hamdan with KampungSukaraja (Figure 6).

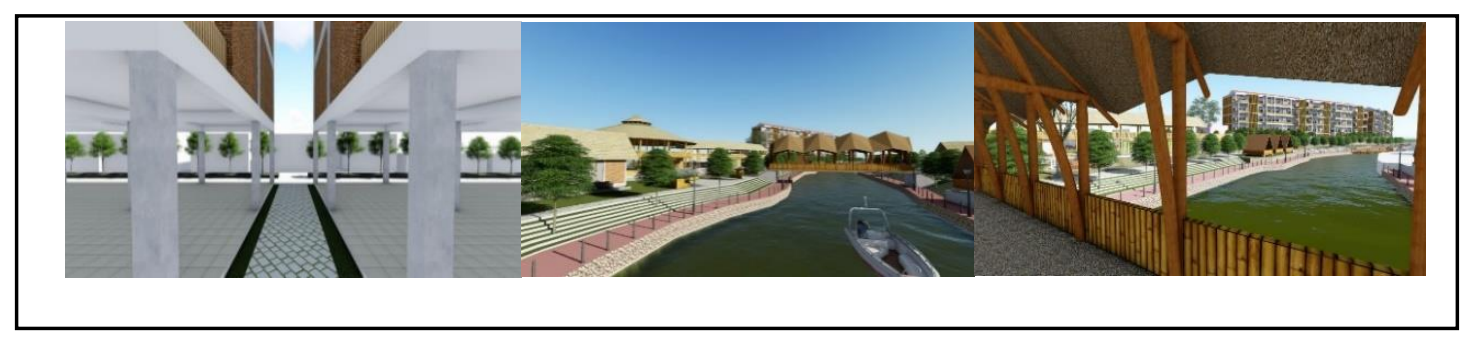

Figure 6 Circulation

\subsection{Landscape Concept}

The function in the site is not only in the form of a centre for children's creativity, but there is also a vertical shelter provided for rearrangement of previously irregular residential areas on the river bank. These two functions are bound together to form a unit that builds the Kampung Hamdan-Sukaraja area into a child-friendly settlement. Can be seen in the site plan (Figure 7), all functions are united by open spaces and public facilities within thesite. 


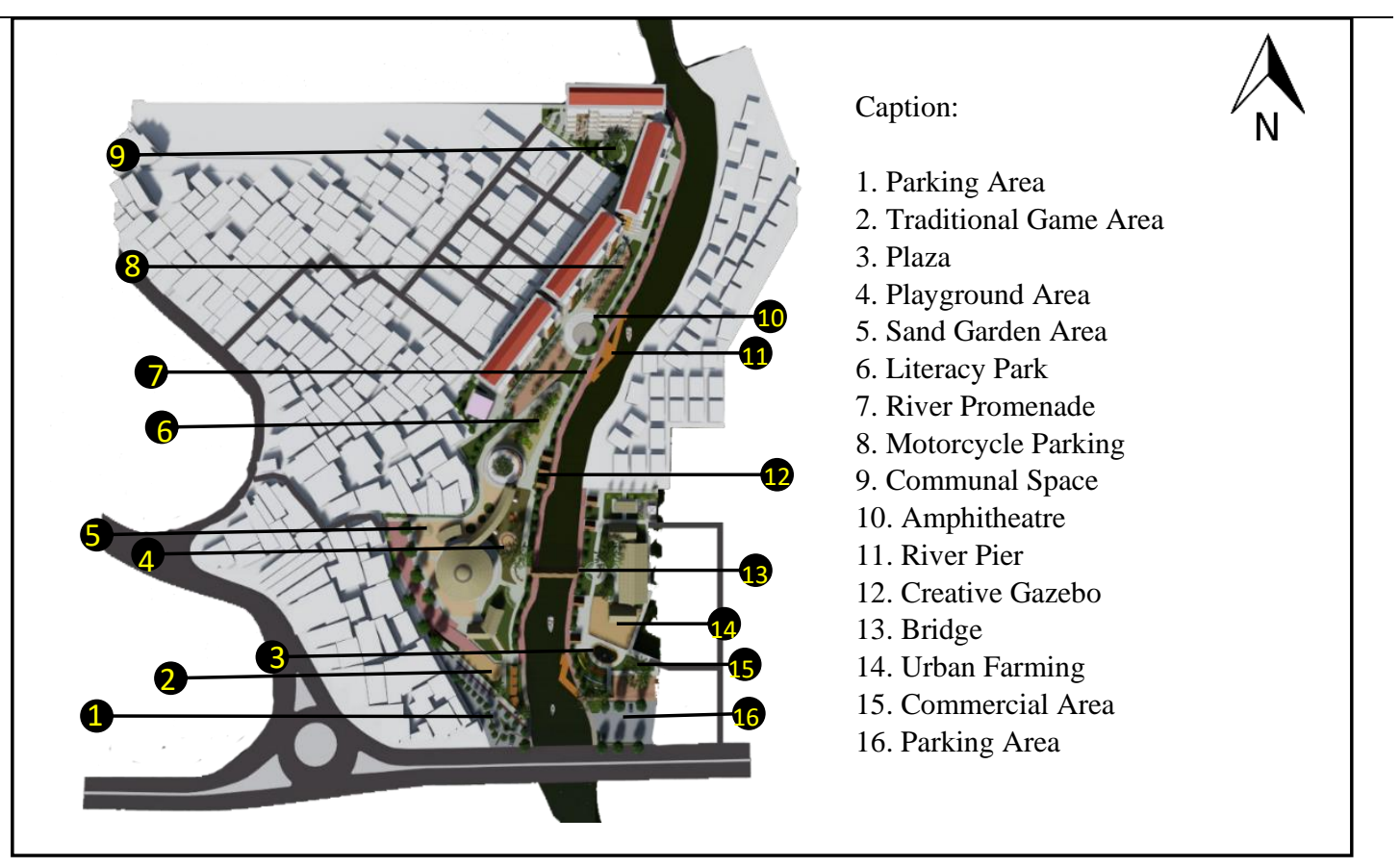

Figure 7 Siteplan

Open space used in this design is the provision of river promenade as a public space to enjoy the Deli River and open space as a liaison between buildings within site as well as a liaison of building masses with Kampung Hamdan-Sukaraja. Open space as aconnecting mass in the form of playgrounds, reading parks, amphitheatre, and communal spaces (Figure 8).

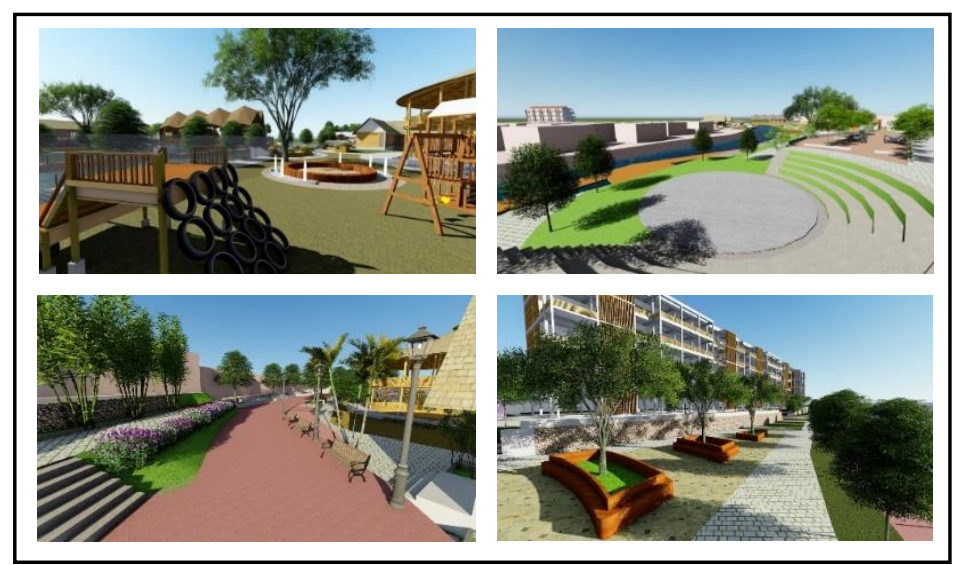

Figure 8 Open Space

\subsection{Respond to Site}

One of the problems at the site on the river bank is flooding. A sufficiently high flood level of about +1.2 meters, making the concept of building design using "houses on stilts" that are applied to all building masses so that more catchment areas so that flooding can be reduced (Figure 9). Another strategy is to increase green open space and vegetation in the site plan. 


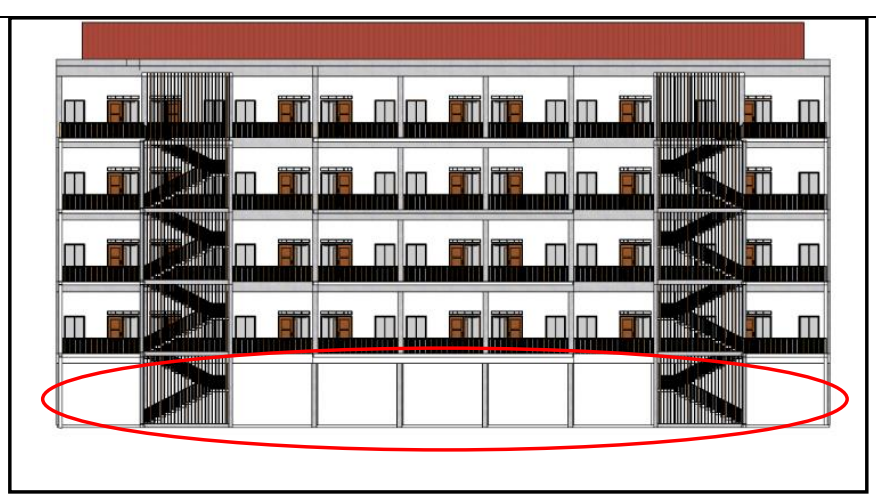

Figure 9 The Stage Building Concept

Potential utilisation of the river is to make a river promenade and make it a public space. The response of the building mass to the site is to have a facade design that leads to the river (Figure $10)$.

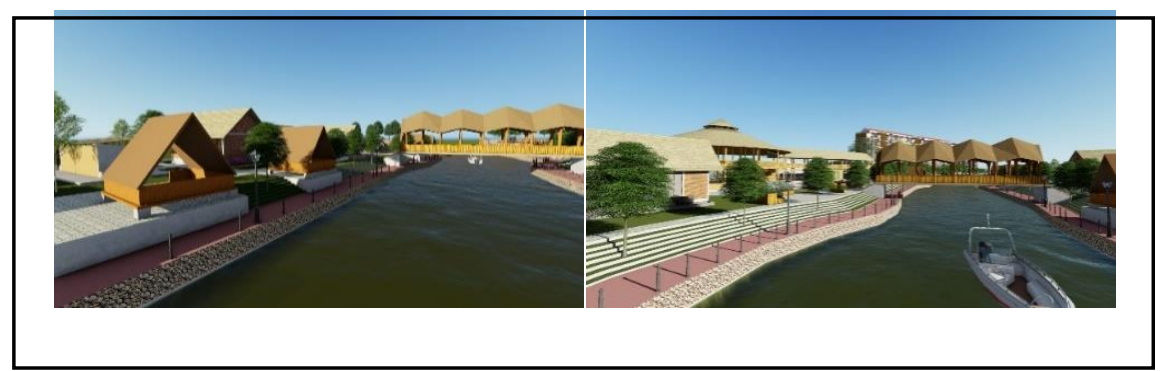

Figure 10 Respond to Site Potential

\subsection{Respond to Human}

The supporting factors for implementing child-friendly settlements are community awareness of the importance of child development, sustainable socialization and good cooperation between communities. Meanwhile, the inhibiting factors in implementing child-friendly settlements are the minimal availability of funds, lack of monitoring and evaluation from a higher level so that motivation is reduced[14].

Kampung Hamdan-Sukaraja community has a lower economic level. To be able for manage and maintain the facilities of a creative centre for children, it can be carried out community empowerment in order to be able to improve their living standards and realise Kampung Hamdan-Sukaraja as a child-friendly settlement. It requires acorrelation between the facilities designed and the process of empowering local communities. The area of entrepreneurship, craft activities, and urban farming planned in the design will be used as a source of income in maintaining child-friendly facilities while enhancing the social and the economic welfare of the local community with work produced and marketed (Figure 11). 


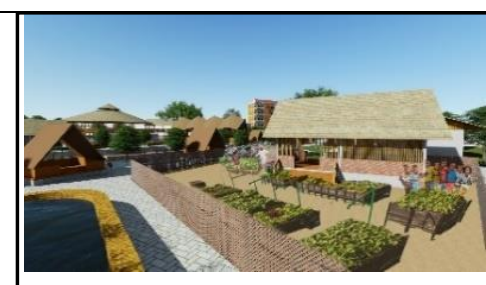

The area of urban farming teaches children to grow crops, as well as a source of income for the community from crop yields.

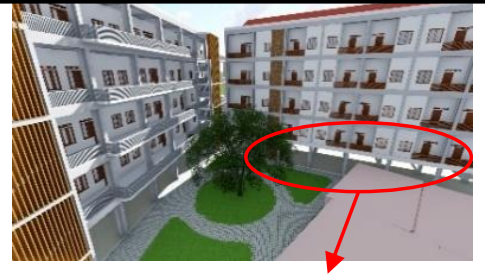

The lower part of the vertical housing is used as an entrepreneurial area.

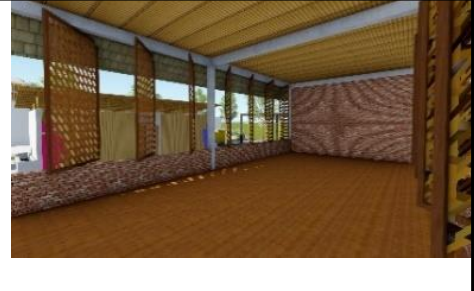

Workshop space that can be used by the community and also training for children.

Figure 11 Community Empowerment Facilities

\subsection{Affordable and Simple Concept}

Child-friendly facilities that are affordable to all levels of society are the main concepts in this design. Therefore, in the design of this Creativity Center emphasises low cost, simple technology, and easy maintenance. Bamboo material which is quickly available and inexpensive become a reason to use in this design, and the maintenance is also not difficult. The bamboo structure is combined with the concrete structure in the column so that bamboo is more durable, considering that this area often floods. Then, in vertical residential areas with more complex structures, it is expensive to pay for the main structure. So the use of bamboo plaster walls can reduce construction costs to make it cheaper (Figure 12). One of the old technologies that continue to be developed is plaster bamboo walls. With its current development, plaster bamboo is not only a bearing wall but can be used as an infill wall or made in a pre-fabricated manner[15].

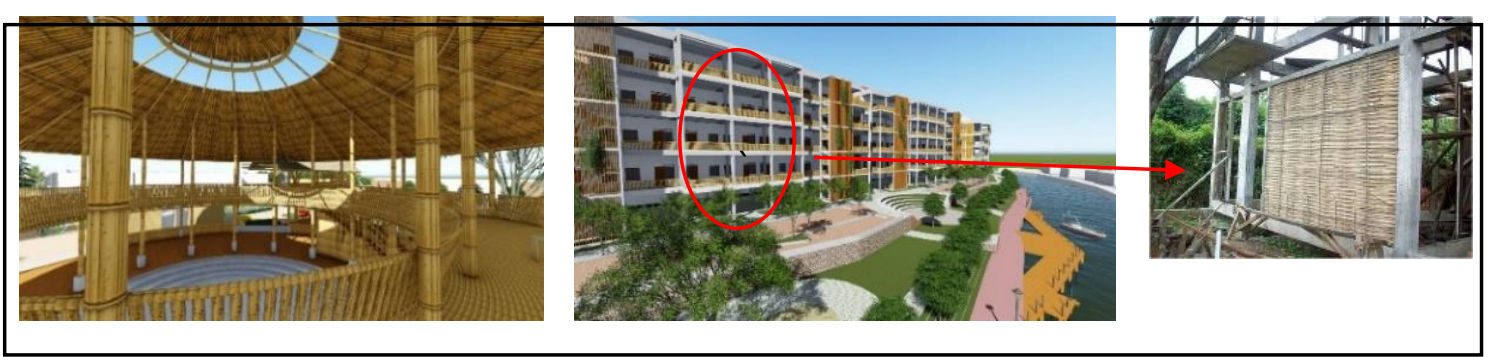

Figure 12 The Use of Inexpensive Material

\subsection{Behaviour Architecture Approach}

The use of Behaviour Architecture themes in buildings is the approach of children's behaviour. Application of the theme to buildings wasdescribed in the following table (Table 1). 
Table 1 Behaviour Architecture Approach to Building

\begin{tabular}{l} 
No. $\quad$ Behaviour Architecture Approach \\
\hline 2
\end{tabular}

The use of ramps as a safe and comfortable circulation for
children who tend to be actively moving.
Column free space that facilitates the movement of children
when playing and hanging out with their friends.

\section{Conclusion}

Creativity Center for Child-Friendly Settlements in Kampung Hamdan-Sukaraja is providing a forum for the development of children's creativity and talent interests through fun play and learning activities as well as participating in training activities for their personal development. 
This facility was designed in a simple and fun way for children in Kampung Hamdan-Sukaraja. The basic concept used is a design that uses a child behaviour approach and the concept of flood response for the safety and comfort of children in their activities.

With thedesign of Child Creativity Center, it is expectedfor a begin to realising Kampung Hamdan-Sukaraja to be a child-friendly village that has child-appropriate space and facilities to play and develop creative and innovative souls, to express, and reduce children's addiction to gadgets by introducing children with values local social and cultural values through traditional games. Also, the location of the building located on the banks of the deli river makes the Children's Creativity Center play a role in reviving the image of the deli river as a pleasant public space.

\section{Acknowledgement}

This research is a study on the design of Children's Creativity Center whichis expect to be a recommendation for the city governments as a solution to providing an affordable child-friendly area for all society and to make dense slums settlements become child-friendly settlements.

\section{REFERENSCES}

[1] U. Munandar, Pengembangan Kreativitas Anak Berbakat. Jakarta: Rineka Cipta, 2009.

[2] V. H. Makarau and J. A. R. Sondakh, "Pusat Pengembangan Kreativitas dan Minat Anak di Manado (Ekspresi Bentuk)," pp. 113-122.

[3] F. P. Saidi, "Graha Seni dan Kreativitas Anak di Manado (Perilaku Dalam Arsitektur)," J. Arsit. DASENG, vol. 2, no. 2, pp. 129-141, 2013.

[4] A. Priyanto, "Pengembangan Kreativitas Pada Anak Usia Dini Melalui Aktivitas Bermain," no. 02, 2014.

[5] C. Rusmiyati and E. Hikmawati, "Implementasi Program Kampung Ramah Anak: dari Kampung Hitam Menuju Layak Anak," J. Pelayanan Kesejaht. Sos., vol. 17, no. 2, pp. 165-178, 2018.

[6] Suciati, Komunikasi Interpersonal Sebuah Tinjauan Psikologis Dan Perspektif Islam. Yogyakarta: Buku Litera, 2015.

[7] P. A. Chusna, "Pengaruh Media Gadget Pada Perkembangan Karakter Anak," pp. 315330, 2017.

[8] K. Pebryawan, "Engklek Sebagai Sarana Pembelajaran Yang Asik Di Tengah Permainan Modern," Magistra, vol. 92, no. 27, pp. 62-68, 2015.

[9] I. Yani, "Stimulasi Perkembangan Anak Melalui Permainan Tradisional Suku Batak Toba," JIV-Jurnal Ilm. Visi, vol. 12, no. 2, pp. 89-98, 2017, doi: 10.21009/jiv.1202.1.

[10] Y. Mangunwijaya, Wastu Citra: Pengantar ke Ilmu Budaya Bentuk Arsitektur, Sendi sendi Filsafatnya Beserta Contoh-contoh Praktis. Jakarta: PT Gramedia Pustaka Utama, 2013.

[11] O. P. Nurkamalina, A. Hardiana, and L. Pramesti, "Penerapan Arsitektur Perilaku Pada Perancangan Sekolah Kreatif di Surakarta," vol. 1, no. 2, pp. 223-232, 2018.

[12] G. Salsabila, L. H. Sari, and R. Priandi, "Pendekatan Child-Friendly Spaces pada Perancangan Pusat Kreativitas Anak di Kota Banda Aceh," vol. 2, no. 3, pp. 12-17, 
2018.

[13] Pemerintah Kota Medan, Peraturan Daerah Kota Medan Nomor 2 Tahun 2015 Tentang Rencana Detail tata Ruang dan Peraturan Zonasi Kota Medan Tahun 2015 - 2035. Medan: Pemkot Medan, 2015.

[14] Jazariyah, "Kampung Ramah Anah Gendeng Sebagai Alternatif Pemenuhan Hak Berkembang Pada Anak Usia Dini," no. 1, pp. 27-38, 2016.

[15] E. Suriani, "Bambu Sebagai Alternatif Penerapan Material Ekologis: Potensi dan Tantangannya," vol. 3, 2017. 